\title{
Typification of the Linnaean name Myosotis nana (Boraginaceae)
}

\author{
Gabriele Galasso $^{1}$ (D) \& Federico Selvi ${ }^{2}$ \\ 1 Sezione di Botanica, Museo di Storia Naturale di Milano, Corso Venezia 55, 20121 Milano, Italy \\ 2 Department of Agriculture, Food, Environment and Forest Sciences, Laboratories of Botany, University of Florence, Piazzale delle \\ Cascine 28, 50144 Firenze, Italy \\ Address for correspondence: Federico Selvi, federico.selvi@unifi.it
}

DOI https://doi.org/10.1002/tax.12065

\begin{abstract}
In this note we designate a lectotype and a supporting epitype for the Linnaean name Myosotis nana L., whose validity has been questioned by some authors. The name is shown to be validly published by Linnaeus and, as such, the correct basionym for Eritrichium nanum (L.) Schrad. ex Gaudin, a well-known European alpine plant.
\end{abstract}

Keywords Alpine flora; Boccone; Boraginaceae-Cynoglosseae; Linnaean names; typification

\section{INTRODUCTION}

The present contribution is part of an ongoing project, supported by the Italian Botanical Society, which aims at providing nomenclatural types for all the vascular plant taxa described from Italy and identify the corresponding loci classici (type localities), in order to improve their systematic knowledge and promote their conservation (Domina \& al., 2012; Passalacqua \& al., 2014; Peruzzi \& al., 2015; Brundu \& al., 2017). This article additionally contributes to ongoing studies in Boraginaceae by Italian botanists (Selvi \& Cecchi, 2009), in particular members of the family sensu lato belonging to the Italian flora (Cecchi \& Selvi, 2014, 2015).

One of these taxa is Eritrichium nanum (L.) Schrad. ex Gaudin, a well-known alpine plant in Boraginaceae subfamily Cynoglossoideae tribe Cynoglosseae (Chacón \& al., 2016) and the only European member of the genus Eritrichium Schrad. ex Gaudin. It is a dwarf, pulvinate and densely hairy perennial plant with bright blue flowers that grows in rocky sites at elevations between 2500 (rarely 1900) and $3750 \mathrm{~m}$ a.s.l. (Selvi, 2018). This species represents a widespread polymorphic complex of closely related taxa including $E$. aretioides (Cham.) DC., E. chamissonis DC., E. nanum s.str. and E. villosum (Ledeb.) Bunge, and growing in the Alps and the Carpathians, the Caucasus, Inner Asia, North Siberia and in the Rocky Mountains from Alaska to Colorado (Zoller \& al., 2002). According to European authors (e.g., Meusel \& al., 1978; Aeschimann \& al., 2004; Valdés, 2011; Selvi, 2018), E. nanum s.str. is endemic to Europe, while the other taxa of the complex occur in Asia and North America (see also Wight, 1902; Murray, 2013). Further studies are needed to address systematic uncertainties in this group, and typification of $E$. nanum is a first necessary step to this purpose. In fact, the name Myosotis nana has never been typified, and the validity of the basionym

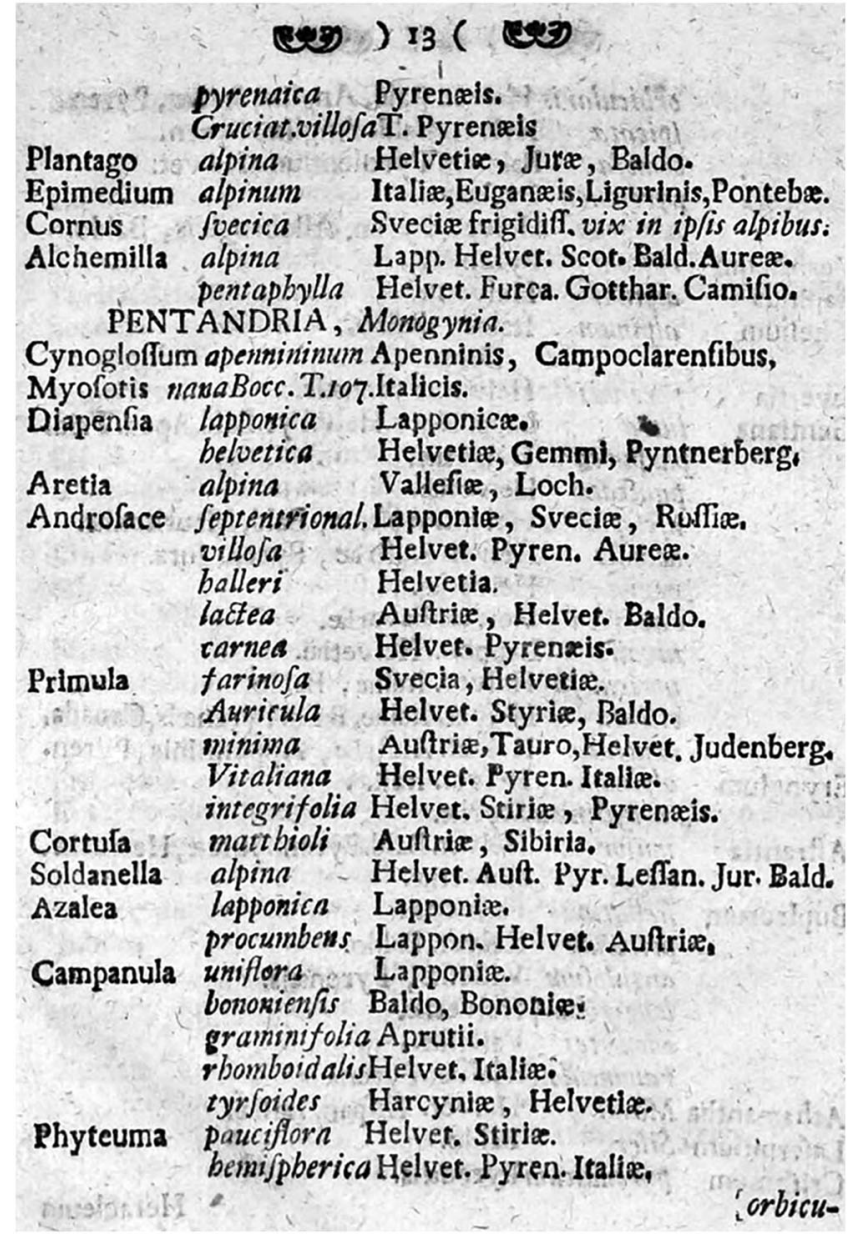

Fig. 1. Page 13 of Linnaeus's Flora alpina (1756) with citation of Myosotis nana and reference to Boccone's plate 107 (see Fig. 2). 
has not been recognized by a number of previous authors (e.g., Wight, 1902; Pignatti, 1982; Federov, 2001; Hilger \& al., 2015; see also the note to the $M$. nana entry in IPNI). This problem is addressed in the present contribution.

\section{TYPIFICATION OF THE NAME}

The name Myosotis nana was first published in 1756 by Linnaeus in the list of "PENTANDRIA, Monogynia" plants given on page 13 of Flora alpina (Linnaeus, 1756). It is generally accepted that Linnaeus was the only author of this book and the new plant names published in it, though Nicolaus N. Åmann defended this work as a thesis at the Uppsala Faculty of Medicine and his name also appears on the title page of the book (K. Gandhi, pers. comm. 2019). The plant is named in the following form: "Myosotis nana Bocc. T. 107. Italicis" (Fig. 1). There is no diagnosis, and for this reason the validity of this name has been questioned by some authors, who considered it as an abbreviated reference to the descriptive phrase name published by Paolo Silvio Boccone in his Museo di piante rare della Sicilia ... (Boccone, 1697), rather than publication of a new binomial (Art. 23.6(a) of the ICN, Turland $\&$ al., 2018; see remark by C. Jarvis in the IPNI entry to M. nana L.). In the complete edition of this book, the polynomial "Echium scorpioides, Alpinum, nanum, supinum" appears on page 149 and, as a "caption" of a plant drawing, besides others, in the upper-right part of plate 107 (Fig. 2), with a slightly different polynomial: "Echium Scorpioides, Alpinum, tomentosus [sic!], nanum, supinum”.

The supposed non-validity of the Linnean name can explain why it does not appear among the taxa in the Linnaean Typification Project and consequently is not treated in the contribution on the types of Linnaean Boraginaceae (Cafferty \& Jarvis, 2004).

Some authors (e.g., Pignatti, 1982; Federov, 2001) attribute the name to Carlo Allioni who validly published it in his Auctuarium ad synopsim methodicam stirpium Horti Reg. Taurinensis (Allioni, 1773: 9). This is a separate pre-print of a paper later published in the journal Mélanges de Philosophie et de Mathematique de la Société Royale de Turin (Allioni, 1774: 61), where there is a reference to page 149 and plate 107 in Boccone (1697), as well as a reproduction of the polynomial description of page 149. Other authors, instead, refer the name Myosotis nana to Domínique Villars (born Villar) who used it in his Prospectus de l'histoire des plantes de Dauphiné (Villars, 1779: 21), without any reference to Linnaeus (1756) or Boccone (1697). Although Villars provided a new description ("Myosotis foliis tomentosis, seminum marginibus serrato-marginatis, invicem conjunctis"), he did not intend to

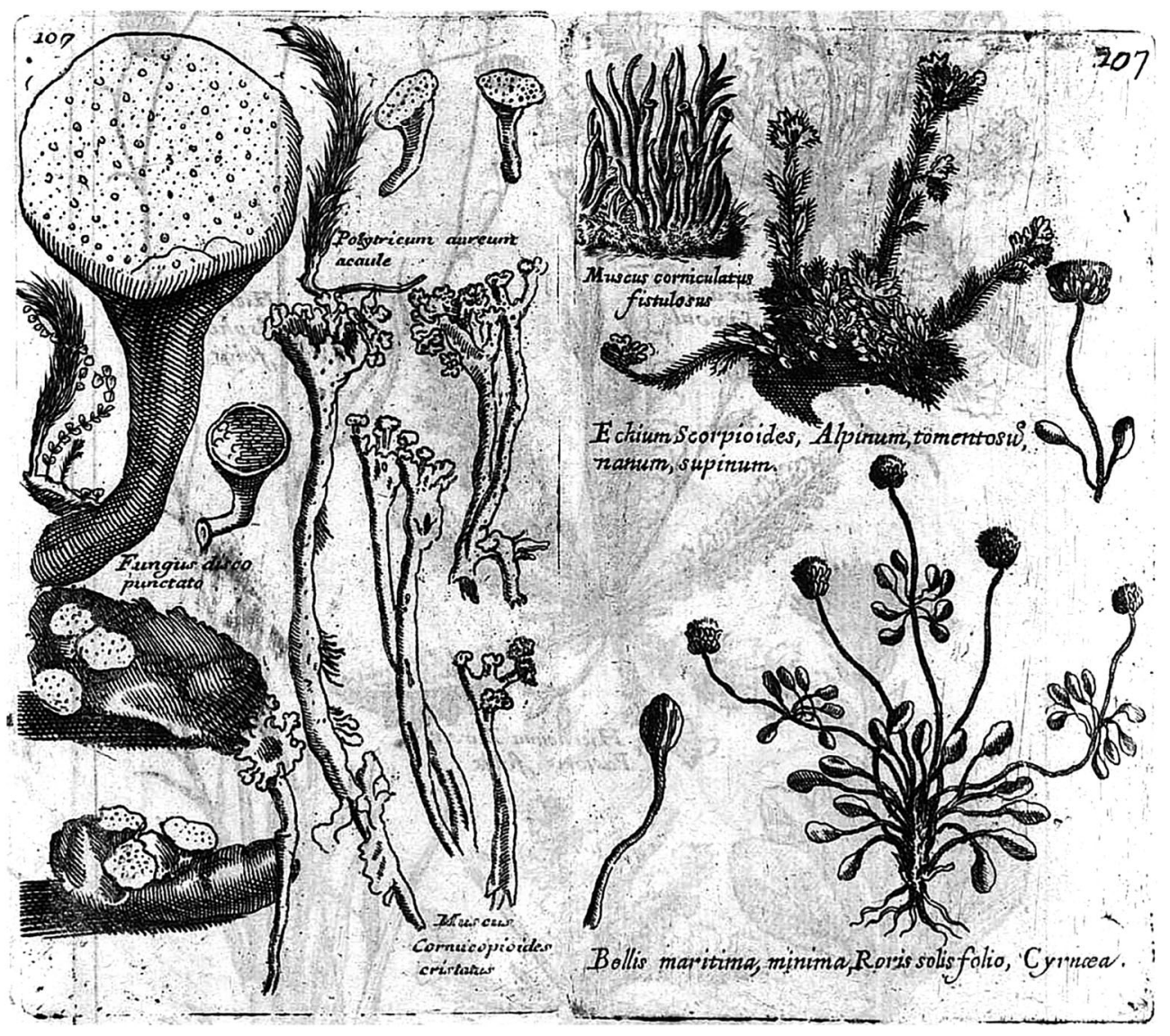

Fig. 2. Plate 107 of Boccone's Museo delle piante rare ... (1697); the lectotype of Myosotis nana L. is at the upper right corner of the plate, described as "Echium Scorpioides, Alpinum, tomentosus, nanum, supinum". 
describe a new species, as shown by the lack of the asterisk that he used to mark the taxa that were newly described in his book (Villars, 1779: 15).

A clear opinion was expressed by Gandhi \& Murray (2013) who concluded that the "correct authority [of M. nana] is Linnaeus, not Amman or Villars or Allioni". This interpretation appears to be correct, though the name Myosotis nana Vill. was again mentioned as basionym for Eritrichium nanum in a recent paper (Hilger \& al., 2015), due to the missing entry of Gandhi and Murray's findings to IPNI (H.H. Hilger, pers. comm. 2019). In fact, Boccone's drawing in the upper-right corner of plate 107 to which Linnaeus referred is sufficiently clear to show that the plant nicely corresponds to our current concept of "Eritrichium nanum". The Latin terms of the polynomial ("Alpinum, tomentosus, nanum, supinum") strongly corroborate this interpretation, as they describe very efficiently the distinctive morphology of the plant, and there is no other taxon of Boraginaceae in Europe corresponding to it. In addition, the plant is thoroughly described in an Italian text on page 149 , where it is also added that it grows in "luoghi aspri, sassosi, ed in sito ove la neve rimane lungo tempo senza liquefarsi nel Monsenis" (on Moncenisio [Mont Cenis], in a rugged and rocky site where the snow remains for long time without melting). Habitat and site details leave no doubts about the identity of this plant, which is relatively common in the Western Alps, Italy, France and Switzerland. Furthermore, the words "Myosotis nana" by Linnaeus (1756: 13) form a true species name, rather than a mention of a generic name followed by the abbreviated phrase name by Boccone (1697), in which the word "Myosotis" does not appear. According to Arts. 38.1, 7.8, and Art. 7 Ex. 10 of the ICN, this Linnaean name is validated solely by the reference to the previously and effectively published diagnosis by Boccone (and not by a reproduction of such diagnosis) and is to be typified by an element selected from the entire context of Boccone's material, either the book or herbarium collections, if existing. For this reason, the specimen of "Myosotis sp." in the Linnean herbarium LINN 180.5, annotated as "Echium scorpioides alpinum nanum Bocc. mihi | e monte Centisio [sic!] Allion." (http://linnean-online.org/2045/) and probably sent to Linnaeus by C. Allioni after the publication of Flora alpina, cannot be used for typification. Actually, no evidence exists about the presence of Eritrichium nanum collections in Boccone's herbaria kept in the Civica e A. Ursino Recupero Libraries of Catania (Pulvirenti \& al., 2017) and in the Naturalis Biodiversity Center in Leiden (the latter as part of the collection of Hieronymus van Beverningh; Costa \& al., 2018). Although existence of this material cannot be excluded, the plant drawing in plate 107 is therefore the only suitable element to serve as lectotype at the present state of knowledge. However, this drawing is miniaturized and included among several other illustrations in the same plate, it does not show taxonomically important details such as flowers and fruits and appears of insufficient quality to serve as a reference for comparison with similar Asian taxa of Eritrichium. In the Boraginaceae, this case is comparable to that of Cynoglossum montanum L., which required the designation of an epitype in accordance with Art. 9.9 of the ICN (Selvi, 2008). The specimen in the Florence Herbarium (FI) here selected as epitype fits the current concept of Eritrichium nanum, matches the original geographical indication by Boccone (Moncenisio) and is a complete collection, hence allowing the examination of morphological details for systematic analyses.

Eritrichium nanum (L.) Schrad. ex Gaudin, Fl. Helv. 2: 57. $1828 \equiv$ Myosotis nana L., Fl. Alp.: 13. $1756 \equiv$ Omphalodes nana (L.) A.Gray in Proc. Amer. Acad. Arts 20: 263. 1885 - Lectotype (designated here): [illustration] "Echium, Scorpioides, Alpinum, tomentosus, nanum, supinum" in Boccone, Museo di Piante Rare della Sicilia, Malta, Corsica, Italia, Piemonte e Germania: [fig. in the upper-right corner of] pl. 107. 1697 - Epitype (designated here): "Eritrichium nanum Schrad., [France] Cenisio: al Lago Bianco, sotto il Malamot, 26 Luglio [Jul] 1894", E. Ferrari 5027 (FI barcode FI018384!).

For images of the lectotype and epitype, see Figs. 2 and 3, respectively.

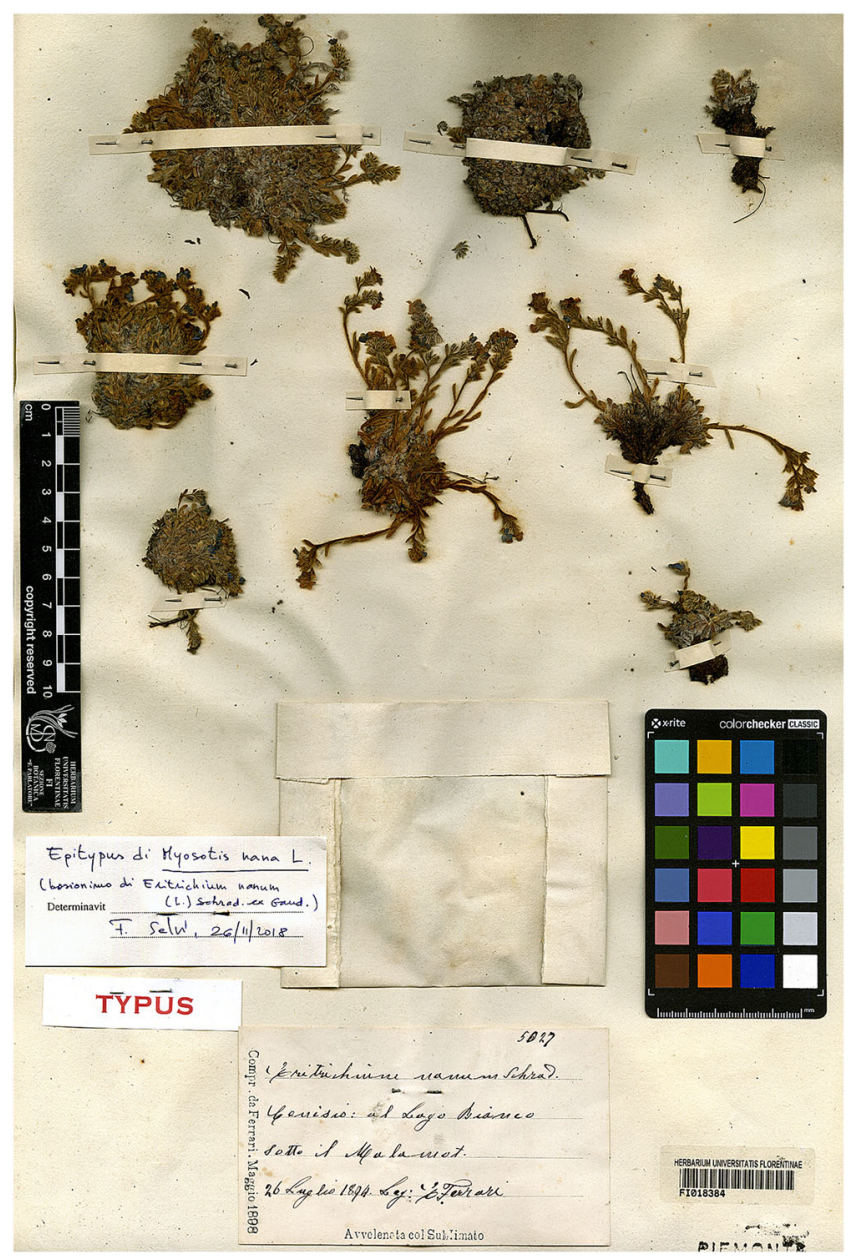

Fig. 3. Epitype of Myosotis nana L. from Mount Cenis (FI barcode FI018384; photo by Chiara Nepi). 


\section{AUTHOR CONTRIBUTIONS}

GG and FS, authors, contributed equally to this manuscript. GG, https://orcid.org/0000-0002-2501-456X; FS, http://orcid.org/00000002-3820-125X

\section{ACKNOWLEDGMENTS}

The authors wish to thank Werner Greuter (Palermo, Berlin), Kanchi Gandhi (Harvard), Hartmut H. Hilger (Berlin), Enrico Banfi (Milano), Lorenzo Cecchi (Firenze) and Fabrizio Bartolucci (Barisciano) for sharing opinions and advice; Rosanna S.M. Costa (Catania) provided information on Boccone's collections, while Chiara Nepi and Lorenzo Cecchi, curators of FI, allowed herbarium searches and kindly provided the scanned image of the epitype specimen.

\section{LITERATURE CITED}

Aeschimann, K., Lauber, K., Moser, D.M. \& Theurillat, J.-P. 2004. Flora Alpina, vol. 2. Bologna: Zanichelli.

Allioni, C. 1773. Auctuarium ad synopsim methodicam stirpium Horti Reg. Taurinensis. Turin.

Allioni, C. 1774. Auctuarium ad synopsim methodicam stirpium Horti Reg. Taurinensis. Mélanges Philos. Math. Soc. Roy. Turin 5: 53-96. https://biodiversitylibrary.org/page/7652418

Boccone, P. 1697. Museo di piante rare della Sicilia, Malta, Corsica, Italia, Piemonte, e Germania. Venetia [Venice]: per io Baptista Zuccato. http://bibdigital.rjb.csic.es/ing/Libro.php?Libro=1490

Brundu, G., Peruzzi, L., Domina, G., Bartolucci, F., Galasso, G., Peccenini, S., Raimondo, F.M., Albano, A., Alessandrini, A., Banfi, E., Barberis, G., Bernardo, L., Bovio, M., Brullo, S., Brunu, A., Camarda, I., Carta, L., Conti, F., Croce, A., Iamonico, D., Iberite, M., Iiriti, G., Longo, D., Marsili, S., Medagli, P., Mariotti, M.G., Pennesi, R., Pistarino, A., Salmeri, C., Santangelo, A., Scassellati, E., Selvi, F., Stinca, A., Vacca, G., Villani, M., Wagensommer, R.P. \& Passalacqua, N.G. 2017. At the intersection of cultural and natural heritage: Distribution and conservation of the type localities of the Italian endemic vascular plants. Biol. Conservation 214: 109-118. https://doi.org/10.1016/j. biocon.2017.07.024

Cafferty, S. \& Jarvis, C. (eds.) 2004. Typification of Linnaean plant names in Boraginaceae. Taxon 53: 799-805. https://doi.org/ $10.2307 / 4135454$

Cecchi, L. \& Selvi, F. 2014. A synopsis of Boraginaceae subfam. Hydrophylloideae and Heliotropioideae in Italy. Pl. Biosyst. 148: 2-12. https://doi.org/10.1080/11263504.2013.873499

Cecchi, L. \& Selvi, F. 2015. Synopsis of Boraginaceae subfam. Boraginoideae tribe Boragineae in Italy. Pl. Biosyst. 149: 630-677. https://doi.org/10.1080/11263504.2015.1057261

Chacón, J., Luebert, F., Hilger, H.H., Ovchinnikova, S., Selvi, F., Cecchi, L., Guilliams, C.M., Hasenstab-Lehman, K., Sutorý, K., Simpson, M.G. \& Weigend, M. 2016. The borage family (Boraginaceae s.str.): A revised infrafamilial classification based on new phylogenetic evidence, with emphasis on the placement of some enigmatic genera. Taxon 65: 523-546. https://doi.org/ $10.12705 / 653.6$

Costa, R.M.S., Van Andel, T., Pavone, P. \& Pulvirenti, S.G. 2018. The pre-Linnaean herbarium of Paolo Boccone (1633-1704) kept in Leiden (the Netherlands) and its connections with the imprinted one in Paris. Pl. Biosyst. 152: 489-500. https://doi.org/10.1080/ 11263504.2018.1445132

Domina, G., Giusso Del Galdo, G., Gargano, D., Labra, M., Peccenini, S., Peruzzi, L. \& Raimondo, F.M. 2012. The Italian
Loci Classici Census. Taxon 61: 1351-1353. https://doi.org/10. $1002 /$ tax.616031

Federov, A.A. (ed.) 2001. Flora of Russia: The European part and bordering regions, vol. 5. Translated from Russian. Rotterdam \& Brookfield: Balkema. [Originally published as Flora Evropeiskoi Chasti SSSR, vol. 5. Leningrad: Nauka Publishers, 1981] https:// books.google.it/books?id=qox $1-x d d 4$ ksC\&hl=de\&source=gbs_ navlinks_s

Gandhi, K.N. \& Murray, D.F. 2013. A note on "Eritrichium Schrad. 1819" and Eritrichium Schrad. ex Gaudin 1828 (Boraginaceae). J. Bot. Res. Inst. Texas 7: 347-349. https://biodiversitylibrary.org/ page $/ 54450268$

Hilger, H.H., Greuter, W. \& Stier, V. 2015. Taxa and names in Cynoglossum sensu lato (Boraginaceae, Cynoglosseae): An annotated synonymic inventory, with links to the protologues and mention of original material. Biodivers. Data J. 3: e4831. https://doi. org/10.3897/BDJ.3.e4831

Linnaeus, C. 1756. Flora alpina. Upsaliae [Uppsala]: excud. L.M. Höjer. http://linnean-online.org/120122/

Meusel, H., Jäger, E., Rauschert, S. \& Weinert, E. 1978. Vergleichende Chorologie der zentraleuropäischen Flora, vol. 2, Karten. Jena: Fischer.

Murray, D.F. 2013. Notes on Eritrichium (Boraginaceae) in North America. J. Bot. Res. Inst. Texas 7: 351-353.

Passalacqua, N., Banfi, E. \& Galasso, G. 2014. Banca dati delle piante endemiche italiane: Protologhi e loci classici. In: Alessandrello, A. (ed.), Al Museo per scoprire il mondo: La ricerca scientifica e le esposizioni. Museo Civico di Storia Naturale di Milano 2010 2013. Natura 104: 33-38.

Peruzzi, L., Domina, G., Bartolucci, F., Galasso, G., Peccenini, S., Raimondo, F.M., Albano, A., Alessandrini, A., Banfi, E., Barberis, G., Bernardo, L., Bovio, M., Brullo, S., Brundu, G., Brunu, A., Camarda, I., Conti, F., Croce, A., Iamonico, D., Iberite, M., Iiriti, G., Longo, D., Manca, A., Marsili, S., Medagli, P., Pistarino, A., Salmeri, C., Santangelo, A., Scassellati, E., Selvi, F., Soldano, A., Stinca, A., Vacca, G., Villani, M.C., Wagensommer, R.P. \& Passalacqua, N.G. 2015. An inventory of the names of vascular plants endemic to Italy, their loci classici and types. Phytotaxa 196: 1-217. https://doi.org/ 10.11646/phytotaxa.196.1.1

Pignatti, S. 1982. Flora d'Italia, vol. 2. Bologna: Edagricole.

Pulvirenti, S.G, Pavone, P., Carbonaro, R.A. \& Costa, R.M.S. 2017. Taxonomic study of the plants to be found in the only herbarium of Paolo Boccone (1633-1704) at present existing in Italy. Pl. Biosyst. 151: 745-759. https://doi.org/10.1080/11263504.2017.1320317

Selvi, F. 2008. Epitypification and identity of Cynoglossum montanum L. (Boraginaceae). Taxon 57: 295-299. https://doi.org/10.2307/ 25065972

Selvi, F. 2018. Boraginaceae. Pp. 138-196 in: Pignatti, S. (ed.), Flora d'Italia, 2nd ed., vol. 3. Bologna: Edagricole.

Selvi, F. \& Cecchi, L. 2009. Typification of names of Euro-Mediterranean taxa of Boraginaceae described by Italian botanists. Taxon 58: 621-626. https://doi.org/10.1002/tax.582025

Turland, N.J., Wiersema, J.H., Barrie, F.R., Greuter, W., Hawksworth, D.L., Herendeen, P.S., Knapp, S., Kusber, W.-H., Li, D.-Z., Marhold, K., May, T.W., McNeill, J., Monro, A.M., Prado, J., Price, M.J. \& Smith, G.F. (eds.) 2018. International Code of Nomenclature for algae, fungi, and plants (Shenzhen Code): Adopted by the Nineteenth International Botanical Congress Shenzhen, China, July 2017. Regnum Vegetabile 159. Glashütten: Koeltz Botanical Books. https://doi.org/10.12705/ Code. 2018

Valdés, B. 2011. Boraginaceae. In: Euro+Med Plantbase - the information resource for Euro-Mediterranean plant diversity. http://ww2.bgbm.org/EuroPlusMed/PTaxonDetail.asp? NameCache $=$ Eritrichium $\% 20$ nanum\&PTRefFk $=7100000$ (accessed 1 Dec 2018). 
Villars, D. [“M. Villar"] 1779. Prospectus de l'histoire des plantes de Dauphiné. Grenoble: Imprimerie Royale. https://books.google.it/ books?id=80hlvQEACAAJ

Wight, W.F. 1902. The genus Eritrichium in North America. Bull. Torrey Bot. Club 29: 407-414. https://www.biodiversitylibrary. org/item/8007\#page/473/mode/1up
Zoller, H., Lenzin, H. \& Erhardt, A. 2002. Pollination and breeding system of Eritrichium nanum (Boraginaceae). Pl. Syst. Evol. 233: 1-14. https://link.springer.com/article/10.1007/s006060200052 